\title{
$\mathbf{N} \mathbf{O} \quad \mathbf{T} \mathbf{E}$
}

\section{Widespread Occurrence of Cucurbita-5, 24-dienol in Cucurbitaceae}

\author{
Toshihiro AKIHISA*, P. GHOSH**, Swapnadip THAKUR**, \\ Fumiko U. RosensteIN***, Toshitake TAMURA*, \\ and Taro MATSUMOTO* \\ * College of Science and Technology, Nihon University (1-8, Kanda Surugadai, Chiyoda-ku, Tokyo T101) \\ ** Department of Chemistry, University of Burdwan (Burdwan, 713104, India) \\ *** Department of Nutrition and Food Science, College of Agriculture, The University of Arizona \\ (Tucson, Arizona, 85721, U.S.A.)
}

The extracted lipids of 28 seed and mature plant (leaves and stems, pericarp of the fruit, and roots) materials from 11 genera of the family Cucurbitaceae were demonstrated to contain cucurbita5,24 -dienol, a cucurbitane type $4^{5}$-unsaturated $3 \beta$-monohydroxy triterpene and present with it in some cases were two $\Delta^{5}$-unsaturated pentacyclic $3 \beta$-monohydroxy triterpenes, glutinol and simiarenol. Cucurbita-5, 24-dienol is considered to be an important intermediate in the biogenesis of cucurbitacins found in Cucurbitaceae.

\section{Introduction}

A number of plants of the family Cucuro bitaceae contain cucurbitacins ${ }^{1), 2)}$, an important group of highly oxygenated tetracyclic triter= penoids having a cucurbitane skeleton and a wide range of biological activities ${ }^{1,3), 4}$. We have recently shown the occurrence of $10 \alpha-$ cucurbita-5, 24-dien-3 $\beta$-ol (cucurbita-5, 24-di= enol) (1), which represents the parent com $=$ pound of cucurbitacins, in the seeds of some Cucurbitaceae including Lagenaria leucantha var. Gourda (gourd) ${ }^{5)}$. More recently, it has been demonstrated that the triterpene (1) was a precursor in the biosynthesis of cucurbitacin-C in the seedlings of Cucumis sativus ${ }^{6)}$ which prompted us to examine the occurrence of (1) in the plant materials of a further species of the family Cucurbitaceae. This paper described the demonstration of widespread occurrence of (1) in the seeds and mature plants of Cucur= bitaceae, which was, in some cases, accom= panied with further two $\Delta^{5}$-unsaturated pentas cyclic $3 \beta$-monohydroxy triterpenes, i.e., $\mathrm{D}: \mathrm{B}-$ friedo-olean-5-en-3 $\beta$-ol (10 $\alpha$-glut-5-en- $3 \beta$-ol; glutinol) (2) and $E$ : B-friedo-hop-5-en-3 $\beta$-ol (10 $\alpha$-adian-5-en-3 $\beta$-ol; simiarenol) (3).

\section{Experimental}

\subsection{General Methods}

Crystallizations were performed in acetonemethanol $(\mathrm{MeOH})$. Melting points $(\mathrm{mp})$ taken on a heated block were uncorrected. Unsa= ponifiable lipid was obtained from a lipid by saponification with $5 \% \mathrm{KOH}$ in $\mathrm{MeOH}$ under reflux followed by extraction with isopropyl ether. Acetylation was performed in acetic anhydride-pyridine at room temp. overnight. Preparative thin-layer chromatography (TLC) on silica gel $(20 \times 20 \mathrm{~cm}, 0.5 \mathrm{~mm}$ thick $)$ was developed 3 times using hexane-ethyl acetate $(6: 1)$. Gas liquid chromatography (GLC) was performed on an OV-17 glass capillary column $\left(30 \mathrm{~m} \times 0.3 \mathrm{~mm}\right.$ i.d., column temp. $\left.260^{\circ} \mathrm{C}\right)$ un $=$ der the conditions already described ${ }^{7)}$. The relative retention time (RRT) values were tas ken relative to cholesteryl acetate. Mass spec tra (EI-MS, $70 \mathrm{eV}$ ) were taken on a gas chros matograph-mass spectrometer (GC-MS) equips ped with a glass column $(2 \mathrm{~m} \times 3 \mathrm{~mm}$ i.d., column temp. $270^{\circ} \mathrm{C}$ ) packed with a $2 \%$ OV17 on Gas Chrom-Z. Proton nuclear magnetic resonance $\left({ }^{1} \mathrm{H} \mathrm{NMR}\right)$ spectra $(100 \mathrm{MHz})$ were recorded in a $\mathrm{CDCl}_{3}$ solution, with tetra= methylsilane as an internal standard. 


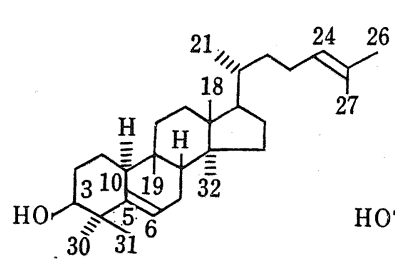

(1)

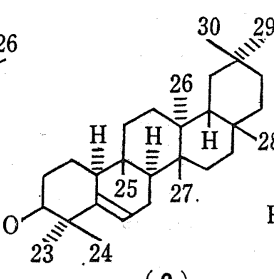

( 2 )

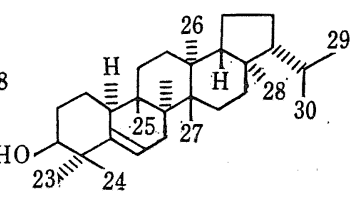

(3)

\subsection{Materials, Extraction and Separa= tion of Triterpene Alcohol Fraction}

Twenty-eight seed and mature plant mate= rials obtained from 22 species of 11 genera of the family Cucurbitaceae used in this study are shown in Table-1. The sources of the plant materials were described in our previous artic cle $^{8)}$. Cucurbita-5, 24-dienol (1) ${ }^{5)}$, glutinol $(2)^{7)}$, and simiarenol $(3)^{7)}$ were used as the refer $=$ ence triterpenes. Extraction of lipid from air-dried materials was performed by either of the following four methods: (a), extracted with $\mathrm{CHCl}_{3}-\mathrm{MeOH}(2: 1)$ at room temp. under stirring; (b) and (c), with $\mathrm{CH}_{2} \mathrm{Cl}_{2}$ and $\mathrm{CHCl}_{3}$ in a Soxhlet extractor, respectively; and (d), with $\mathrm{MeOH}$ under reflux, and the extract was then treated with cold acetone to remove ins soluble phospholipid; the acetone soluble por $=$ tion was subjected to subsequent work. The unsaponifiable lipid obtained from the extract was separated, on preparative TLC, into two triterpene alcohol fractions: one contained the triterpenes with an axially oriented $3 \beta$-monos hydroxyl group [referred to as triterpene (A)] $\left(R_{f}=0.53\right)$ such as (1), and the other cons tained the usual triterpenes ${ }^{9)}$ with an equas torial $3 \beta$-monohydroxyl group [referred to as triterpene (B)] $\left(R_{f}=0.44\right)$; in addition to sterol $\left(R_{f}=0.28\right)^{8)}$ and several other fractions. The triterpene (A) fraction was acetylated and the resulted acetate fraction was subjected to GLC and GC-MS analyses.

\section{Results and Discussion}

Isolation and identification of the triterpenes from the triterpene (A) fractions of the seeds of Trichosanthes japonica, the pericarp of fruits and the aerial parts of Sechium edule was performed as described below.

Soxhlet extraction of the dried and ground seeds (500 g) of $T$. japonica afforded a lipid (106 g) from which was obtained an unsaponic fiable lipid (1.24 g). This was fractionated by preparative TLC giving triterpene (A) fraction (143 mg) which was then acetylated to yield the acetate $(140 \mathrm{mg})$. GLC showed that the acetate was constituted of only one component with $\mathrm{RRT}=1.43\left(\mathrm{mp} .117 \sim 118^{\circ} \mathrm{C}\right)$ which afforded the following spectroscopic data: MS: $m / z 468\left(\mathrm{M}^{+}\right.$, rel. int. 5\%), 453(3\%), 408 (18\%), 383 (12\%), 298 (3\%), 274 (100\%), 259 (68\%), 255 (5\%), 231 (11\%), 205 (12\%). ${ }^{1} \mathrm{H}$ NMR : $\delta 0.81\left(3 \mathrm{H}, s, 18-\mathrm{H}_{3}\right), 0.85(3 \mathrm{H}, s$, $\left.32-\mathrm{H}_{3}\right), 0.91\left(3 \mathrm{H}, s, 19-\mathrm{H}_{3}\right), 1.04(6 \mathrm{H}, s, 30-$ $\left.\mathrm{H}_{3}, 31-\mathrm{H}_{3}\right), 2.01(3 \mathrm{H}, s, 3 \beta-\mathrm{OAc}), 0.88(3 \mathrm{H}$, $\left.d, J=5.9 \mathrm{~Hz}, 21-\mathrm{H}_{3}\right), 1.59\left(3 \mathrm{H}, s, 27-\mathrm{H}_{3}\right), 1.68$ $\left(3 \mathrm{H}, s, 26-\mathrm{H}_{3}\right), 4.70\left(1 \mathrm{H}, m, W_{1 / 2}=5.9 \mathrm{~Hz}, 3\right.$ $\alpha-\mathrm{H}), 5.51\left(1 \mathrm{H}, m, W_{1 / 2}=10.0 \mathrm{~Hz}, 6-\mathrm{H}\right), 5.09$ ( $1 \mathrm{H}, t, J=7.3 \mathrm{~Hz}, 24-\mathrm{H})$. The assignment of the proton signals, done as above, was perc formed by the ${ }^{1} \mathrm{H}$ NMR study using a lantha= nide shift reagent ${ }^{10)}$. The chromatographic and spectroscopic data were consistent with those of authentic cucurbita-5, 24-dienol (1) acetate (lit. ${ }^{5)} \mathrm{mp} 115 \sim 117^{\circ} \mathrm{C}$ ), and, hence, the triterpene was identified as the acetate of (1).

Soxhlet extraction of the dried and ground pericarp $(720 \mathrm{~g})$ from the fruits $(9610 \mathrm{~g})$ of $S$. edule gave a lipid ( $24 \mathrm{~g}$ ). The unsaponifiable lipid (919 mg) obtained from the lipid was subjected to preparative TLC yielding triter= pene (A) fraction $(7.0 \mathrm{mg})$ which was then acetylated to give an acetate fraction $(7.1 \mathrm{mg})$. GLC of the acetate showed that it to be a mixture of the components with RRT 1.43 (3 $\%)$ and 1.89 (87\%) accompanied with several other components (10\%). The triterpene with RRT 1.43 was identified as the acetate of (1) by the GLC and GC-MS data. Crystallization of the acetate fraction enabled the enrichment of the component with RRT 1.89 (96\% pure by $\mathrm{GLC}, 3 \mathrm{mg}$ ) ( $\mathrm{mp} 191 \sim 194^{\circ} \mathrm{C}$ ) which pros vided the following spectroscopic data: MS: m/z $468\left(\mathrm{M}^{+}\right.$, rel. int. 1\%), 408 (81\%), 393 (23 
Table-1 Cucurbitaceae plants investigated, triterpene (A) contents of dried plant materials, and triterpene (A) compositions (\%).

\begin{tabular}{|c|c|c|c|c|c|c|c|}
\hline \multirow{2}{*}{ Cucurbitaceae } & \multirow{2}{*}{$\begin{array}{c}\text { Plant } \\
\text { material }\end{array}$} & \multirow{2}{*}{$\begin{array}{c}\text { Lipid } \\
\text { extrac }= \\
\text { tion }^{a)}\end{array}$} & \multirow{2}{*}{$\begin{array}{l}\text { Content of } \\
\text { triterpene } \\
\text { (A) } \\
\text { mixture }^{b}\end{array}$} & \multicolumn{4}{|c|}{ Compositions (\%) } \\
\hline & & & & $(1)$ & (2) & (3) & Others \\
\hline Apodanthera undulata Gray & Seeds & (a) & 5.9 & 23 & & & 77 \\
\hline Benincasa cerifera Savi (wax gourd) & Seeds & (b) & - & 2 & 16 & 2 & 80 \\
\hline \multirow[t]{2}{*}{ Citrullus battich Forskål (watermelon) } & Seeds & $(\mathrm{b})$ & 17.2 & 100 & & & \\
\hline & Aerial parts & $(d)$ & 11.5 & 11 & 35 & & 44 \\
\hline Cucumis melo L. (melon) & Seeds & (b) & 16.3 & 100 & & & \\
\hline \multirow[t]{2}{*}{ C. sativus $\mathrm{L}$. (cucumber) } & Seeds & (b) & 2.3 & 8 & & & 92 \\
\hline & Aerial parts & (d) & 19.9 & 11 & 40 & & 49 \\
\hline Cucurbita digitata & Seeds & (a) & 59.4 & 100 & & & \\
\hline C. foetidissima HBK (buffalo gourd) & Seeds & (a) & 13.5 & 23 & & & 77 \\
\hline C. maxima Duschesne (squash) & Seeds & (b) & - & 41 & & & 59 \\
\hline C. pepo L. (pumpkin) & Seeds & (b) & - & 100 & & & \\
\hline Gynostemma pentaphyllum Makino & Aerial parts & $(d)$ & 7.8 & 11 & & & 89 \\
\hline $\begin{array}{l}\text { Lagenaria leucantha Rusby var. } \\
\text { Gourda Makino (bottle gourd) }\end{array}$ & Seeds & $(\mathrm{b})$ & 41.3 & 100 & & & \\
\hline \multirow[t]{2}{*}{ L. leucantha Rusby var. depressa Makino } & Seeds & $(\mathrm{b})$ & 28.8 & 100 & & & \\
\hline & Pericarp & (b) & 1.0 & 71 & & & 29 \\
\hline L. leucantha Rusby & Seeds & (c) & - & 100 & & & \\
\hline Luffa acutangula Roxb. & Seeds & (c) & - & 22 & 3 & & 75 \\
\hline L. cylindrica Roem. (sponge gourd) & Seeds & (b) & 10.0 & 100 & & & \\
\hline \multirow[t]{2}{*}{ Momordcia charantia L. (balsam pear) } & Seeds & (b) & 9.8 & 100 & & & \\
\hline & Aerial parts & (c) & - & 100 & & & \\
\hline M. charantia L. var. Pavel Crantz & Seeds & (b) & 2.5 & 44 & & & 45 \\
\hline M. cochinchinensis Spreng & Seeds & (c) & - & 1 & 70 & & 29 \\
\hline \multirow[t]{2}{*}{ Sechium edule Sw. (chayote) } & Aerial parts & (d) & 2.7 & 4 & 5 & 88 & 3 \\
\hline & Pericarp & (b) & 1.0 & 2 & 87 & & 10 \\
\hline $\begin{array}{l}\text { Trichosanthes anguina L. } \\
\text { (serpent cucumber) }\end{array}$ & Seeds & (c) & - & 5 & 58 & & 37 \\
\hline T. dioica & Roots & (c) & - & 100 & & & \\
\hline \multirow[t]{2}{*}{ T. japonica Regel } & Seeds & (b) & 28.7 & 100 & & & \\
\hline & Roots & (d) & 0.4 & 100 & & & \\
\hline
\end{tabular}

a) See experimental section.

b) Contents of triterpene (A) (mg) from dried plant material (seeds or mature plants) (100 g).

\%), $274(66 \%), 259(59 \%), 205(37 \%), 187(30$ \%), $173(62 \%), 134(92 \%), 121(96 \%), 109(100$ \%). ${ }^{1} \mathrm{H} \mathrm{NMR}^{10)}: \delta 0.85\left(3 \mathrm{H}, s, 25-\mathrm{H}_{3}\right), 0.95$ $\left(3 \mathrm{H}, s, 29-\mathrm{H}_{3}\right), 0.99\left(3 \mathrm{H}, s, 30-\mathrm{H}_{3}\right), 1.00(3$ $\left.\mathrm{H}, s, 26-\mathrm{H}_{3}\right), 1.04\left(3 \mathrm{H}, s, 24-\mathrm{H}_{3}\right), 1.07(3 \mathrm{H}$, $\left.s, 23-\mathrm{H}_{3}\right), 1.10\left(3 \mathrm{H}, s, 27-\mathrm{H}_{3}\right), 1.16(3 \mathrm{H}, s$, $\left.28-\mathrm{H}_{3}\right), 2.01(3 \mathrm{H}, s, 3 \beta-\mathrm{OAc}), 4.69(1 \mathrm{H}, m$, $\left.W_{1 / 2}=4.7 \mathrm{~Hz}, 3 \alpha-\mathrm{H}\right), 5.56\left(1 \mathrm{H}, m, w_{1 / 2}=7.4\right.$ $\mathrm{Hz}, 6-\mathrm{H})$. These data were almost identical with those of authentic glutinol (2) acetate (lit. ${ }^{11)} \mathrm{mp} 192 \sim 194^{\circ} \mathrm{C}$ ), and, hence, the triter= pene with RRT 1.89 was identified as the acetate of (2).
Extraction with $\mathrm{MeOH}$ of the dried and ground aerial parts $(1220 \mathrm{~g})$ of $S$. edule gave a lipid (93 g) which on treatment with cold acetone gave an acetone soluble lipid (29 g). Saponification of the lipid yielded an unsac ponifiable lipid (1.37g) from which was obtained triterpene. (A) fraction (34 mg) by preparative TLC. This was acetylated, and the resulted acetate fraction was shown by GLC to contain the components with RRT 1.43.(5\%), $1.89(4 \%)$, and $2.40(88 \%)$, in addition to several other components (3\%). Two triter= penes with RRT 1.43 and 1.89 were identic 
fied as the acetates of (1) and (2), respectio vely, by GLC and GC-MS. Crystallization of the acetate fraction enabled the enrichment of the component with RRT 2.40 (98\% pure by GLC, $8 \mathrm{mg}$ ) (mp $217 \sim 218^{\circ} \mathrm{C}$ ) which exhibited the following spectroscopic data: MS: $\mathrm{m} / \mathrm{z} 468$ $\left(\mathrm{M}^{+}\right.$, rel. int. 1\%), $453(2 \%), 408(22 \%), 393$ (10\%), 274 (93\%), $259(100 \%), 245(13 \%), 236$ (32\%), 207 (26\%), $134(95 \%), 122(98 \%) .{ }^{1} \mathrm{H}$ $\mathrm{NMR}^{10)}: \delta 0.78\left(3 \mathrm{H}, s, 28-\mathrm{H}_{3}\right), 0.89(3 \mathrm{H}, s$, $\left.25-\mathrm{H}_{3}\right), 0.92\left(3 \mathrm{H}, s, 26-\mathrm{H}_{3}\right), 1.01(3 \mathrm{H}, s, 27-$ $\left.\mathrm{H}_{3}\right), 1.04\left(3 \mathrm{H}, s, 24-\mathrm{H}_{3}\right), 1.07\left(3 \mathrm{H}, s, 23-\mathrm{H}_{3}\right)$, $2.02(3 \mathrm{H}, s, 3 \beta$-OAc), 0.82 and 0.89 (each 3 $\mathrm{H}, d$, and $\left.J=6.3 \mathrm{~Hz}, 29-\mathrm{H}_{3}, 30-\mathrm{H}_{3}\right), 4.69$ (1 $\left.\mathrm{H}, m, W_{1 / 2}=4.7 \mathrm{~Hz}, 3 \alpha-\mathrm{H}\right), 5.54\left(1 \mathrm{H}, m, W_{1 / 2}\right.$ $=7.4 \mathrm{~Hz}, 6-\mathrm{H})$. These data were consistent with those of authentic simiarenol (3) acetate (lit. ${ }^{12)} \mathrm{mp} .216 \sim 217^{\circ} \mathrm{C}$ ). Hence, the triterpene with RRT 2.40 was identified as the acetate of (3).

Identification of the triterpenes (1), (2), and (3) in the plant materials, other than those described above, was performed by GLC and GC-MS. Table-1 showed the contents of triterpene (A) fractions of the dried plant materials which were determined based on the amounts of the triterpene (A) fractions recos vered, and the compositions of the triterpene (A) fractions which were determined by GLC. Although the natural occurrence of the triter= pene (1) has heretofore been known only in the seeds of Lagenaria leucantha var. Gours da, Citrullus battich, Cucurbita pepo, and Trichosanthes kirilowi $i i^{5)}$, this study demons strated the widespread occurrence of the triter= pene in the seeds and, furthermore, in the mature plant tissues of the cucurbitaceous plants including the above four seed materials. This study has further demonstrated the ocs currence of two other triterpenes, $(2)^{11), 13)}$ and $(3)^{12), 14), 15)}$, which represented the rare classes of triterpenes, in some of the Cucurbitaceae investigated.

The triterpene ( 1 ) is considered to be bios synthesized directly from squalene-2,3-oxide ${ }^{16)}$, and which, on the other hand, is regarded as a key intermediate of the biosynthesis of cus curbitacins $^{6)}$ found in Cucurbitaceae ${ }^{1), 2}$. The co-occurrence of the triterpenes (2) and (3) with (1), all of which possess an axial $3 \beta-$ hydroxyl group and a $\Delta^{5}$-bond, in some cus curbitaceous plant materials is of interest from the biogenetic viewpoint of triterpenoids. The constitutions of the triterpene (B) fractions ${ }^{9)}$, which contain the triterpenes possessing a common equatorial $3 \beta$-hydroxyl group, of $\mathrm{Cu}=$ curbitaceae are under studying.

\section{Acknowledgment}

The authors are grateful to Drs. T. Takido and M. Aimi for the NMR and mass spectra.

(Received July. 10, 1986)

\section{References}

1) D. Lavie and E. Glotter, Fortschr. Chem. Org. Naturst., 29, 307 (1971).

2) M.C. Das and S.B. Mahato, Phytochemistry, 22, 1071 (1983).

3) B. Shohat, S. Gitter, B. Lavie, and D. Lavie Cancer Res., 25, 1828 (1965).

4) S.M. Kupchan, R.M. Smith, Y. Aynehchi, and M. Maruyama, J. Org. Chem., 35, 2891 (1970).

5) T. Itoh, T. Tamura, T.M. Jeong, T. Tamura, and T. Matsumoto, Lipids, 15, 122 (1980).

6) G. Balliano, O. Caputo, F. Viola, L. Delprino, and L. Cattel, Phytochemistry, 22, 909 (1983).

7) T. Itoh, H. Tani, K. Fukushima, T. Tamura, and T. Matsumoto, J. Chromatogr., 234, 65 65 (1982).

8) T. Akihisa, P. Ghosh, S. Thakur, F.U. Roo senstein, and T. Matsumoto, J. Am. Oil Chem. Soc., 63, 653 (1986).

9) T. Itoh, T. Shigemoto, N. Shimizu, T. Ta= mura, and T. Matsumoto, Phytochemistry, 21, 2414 (1982).

10) T. Akihisa, N. Shimizu, R. Kawaguchi, T. Tamura, and T. Matsumoto, J. Jpn. Oil Chem. Soc., 35, 907 (1986)

11) F.G. Fischer and N. Seiler, Liebiges Ann. Chem., 644, 162 (1961).

12) K. Nishimoto, M. Ito, S. Natori, and T. Ohmoto. Tetrahedron, 24, 735 (1968).

13) T. Ohmoto, M. Ikuse, and S. Natori, Phyto chemistry, 9, 2137 (1970).

14) H.R. Arthur, S.W. Tam, and V. Angsusingh, Aust. J. Chem., 13, 506 (1960); R.T. Aplin, H.R. Arthur, and W.H. Hui, J. Chem. Soc. (C) 1251 (1966).

15) L. Ogunkoya, O.O. Olubajo, and D.S. Sondha, Phytochemistry, 11, 3093 (1972). 
うり科植物に広範囲に分布する

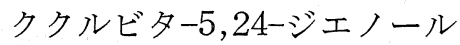

秋久俊博*.P. Ghosh**.S. Thakur**

F.U. Rosenstein***

田村利武*・松本太郎*

*日本大学理学部 (广101 千代田区神田駿河台 1-8)

** Burdwan 大学化学科 (インド Burdwan 市)

*** アリゾナ大学農学部栄養食糧科学科

（米国アリゾナ州ツーソン市）
種子及び成熟組織（茎・葉部, 果肉, 根）の抽出脂質の すべてに， $\Delta^{5}$-結合及び $3 \beta$-ヒドロキシル基をもつクク ルビタン系トリテルペンであるククルビタ-5,24-ジエノ ールの存在を明らかにした。さらに，いくつかのらり科 植物試料には $\Delta^{5}$-結合をもつ五環性トリテルペンアルコ ールであるグルチノールとシミアレノールも検出した。 ククルビター5,24-ジェノールは, 5り科植物に存在の知 られるククルビタシン類の生合成における重要な一中間 体とみなされる。

らり科の 11 属の植物から得られた 28 種類にのぼる 